Dr PETAR DRAGIŠIĆ, naučni saradnik

Institut za noviju istoriju Srbije

UDK 323(497.1)"1991/1999"

Beograd, Trg Nikole Pašića 11

050.48FOREIGN AFFAIRS"1991/1999"

\title{
ČLANCI ČASOPISA FOREIGN AFFAIRS O JUGOSLOVENSKIM RATOVIMA 1991-1999.*
}

\begin{abstract}
APSTRAKT: $U$ članku su analizirani tekstovi objavljivani u američkom stručnom časopisu Foreign Affairs u vreme ratova na prostoru bivše Jugoslavije 90-ih godina prošlog veka. Reč je o radovima poznatih naučnika, novinara, ali i političara koji su neposredno učestvovali u jugoslovenskoj krizi. Razmatrani su njihovi stavovi o uzrocima krize, ulozi medunarodne zajednice, kao i ocene postkonfliktne situacije u zemljamanaslednicama SFRJ.
\end{abstract}

\section{KLJUČNE REČI: Foreign Affairs, SFRJ, rat, Bosna, Kosovo}

Već gotovo jedan vek časopis Foreign Affairs predstavlja teren na kome se prezentuju najvažnija pitanja američke spoljne politike i međunarodnih odnosa u celini. Časopis je 1922. godine pokrenuo Savet za inostrane odnose (Council on Foreign Relations), uticajni američki institut posvećen međunarodnim spoljnopolitičkim pitanjima. Od svojih početaka do danas Foreign Affairs je predstavljao značajan poligon za razmenu mišljenja o najvažnijim spoljnopolitičkim pitanjima i američkoj ulozi u njima.

Za Foreign Affairs pisali su i pišu velika imena nauke, ali i najvažniji politički akteri, među kojima i jugoslovenski predsednik Josip Broz Tito, čiji je esej, „On Certain Current International Questions“, objavljen 1957. godine. ${ }^{1}$ Upravo na stranicama Foreign Affairsa objavljeni su i epohalno značajni tekstovi, poput „X-članaka“ Džordža Kenana iz 1947. godi$\mathrm{ne}^{2}$, ili čuveni članak Semjuela Hantingtona „The Clash of Civilizati-

${ }^{*}$ Rad je deo projekta Tradicija i transformacija - istorijsko nasleđe i nacionalni identiteti u Srbiji u 20. veku (47019), koji finansira Ministarstvo prosvete, nauke i tehnološkog razvoja Republike Srbije.

${ }^{1}$ Josip Broz Tito, „On Certain Current International Questions“, Foreign Affairs, 1 (1957), 68-77.

${ }^{2}$ George F. Kennan, „The Sources of Soviet Conduct“, Foreign Affairs, 4 (1947), $566-582$. 
ons?". ${ }^{3}$ Značaj Foreign Affairsa je, čini se, dvojak. Sa jedne strane, prilozi objavljeni u časopisu, s obzirom na uticaj i renome autora, predstavljaju nezaobilazan izvor za analizu prošlih, aktuelnih, pa i budućih tema međunarodnih odnosa. Sa druge strane, s obzirom na ugled samog časopisa, ne možemo isključiti ni uticaj samog časopisa na donosioce odluka.

Analizom većeg broja članaka Foreign Affairsa učinjen je pokušaj rekonstrukcije inostranih (u prvom redu američkih) pogleda na krizu i ratne sukobe na prostoru bivše Jugoslavije, od početka raspada Jugoslavije i ratova 1991. do NATO kampanje protiv Savezne Republike Jugoslavije 1999. godine. Rad je fokusiran na ispitivanje tumačenja uzroka i posledica jugoslovenske krize, te uloge međunarodnog faktora u ratovima na prostoru nekadašnje Jugoslavije.

\section{Interni uzroci krize}

Autori tekstova o jugoslovenskim ratovima publikovanih $\mathrm{u}$ časopisu Foreign Affairs, posebnu pažnju posvetili su analizi uzroka krvavog raspada jugoslovenske federacije. U članku V. P. Gegnona, „Yugoslavia: Prospects for Stability", koji je u Foreign Affairsu objavljen u proleće 1991. godine, neposredno pre eskalacije jugoslovenske krize, autor je kao uzrok krize u Jugoslaviji označio nacionalizam, i to pre svega srpski. U tom kontekstu autor ističe Memorandum Srpske akademije nauka i umetnosti, te konstatuje da je Milošević po preuzimanju vlasti u Srbiji nastavio da „eksploatiše nacionalno pitanje“, okrenuvši se populističkoj i šovinističkoj verziji srpskog nacionalizma. ${ }^{4}$

Za ondašnje tenzije u Jugoslaviji (u proleće 1991) Gegnon je okrivio i hrvatsku stranu. Etnički konflikti u Hrvatskoj su, po njemu, posledica kombinacije hrvatskog nacionalizma i „provokacija srpskih ekstremista“ izvan Hrvatske. Autor precizira da je HDZ-ov režim započeo sa izbacivanjem Srba iz administracije i policijskog aparata. Lokalni srpski ekstremisti su zaigrali na kartu strahova od Tuđmanovog režima i evocirali sećanja na masakre Srba u NDH. Rezultat je bio konsolidovanje srpske vlasti u južnim i istočnim delovima Hrvatske. ${ }^{5}$ Ipak, prema Gegnonu, za tenzije u Hrvatskoj i za celokupnu jugoslovensku krizu bio je pre svega odgovoran srpski faktor. Srpsko rukovodstvo je predstavljalo ključnu prepreku kreiranju nove forme jugoslovenske države, koja bi bila zasnovana na principima tržišne privrede, višestranačke demokratije i privatnog vlasništva. ${ }^{6}$

\footnotetext{
${ }^{3}$ Samuel P. Huntington, „The Clash of Civilizations?", Foreign Affairs, 3 (1993), 22-49.

${ }^{4}$ V. P. Gagnon, Jr, „Yugoslavia: Prospects for Stability”, Foreign Affairs, 3 (1991), 21.

${ }^{5}$ Isto, 29-30.

${ }^{6}$ Isto, 32 .
} 
Uzrocima jugoslovenske tragedije bavila se, $\mathrm{u}$ članku objavljenom $\mathrm{u}$ jesen 1992. godine, i Sabrina Ramet. Odgovornost za jugoslovensku tragediju Ramet pripisuje isključivo srpskoj strani. Autorka za korenima takve politike, vraćajući se na period između dva svetska rata. Naglašava forsiranje centralističke koncepcije državne strukture, koju su tada zastupale vlasti u Beogradu, a koja je, nastavlja Ramet, ignorisala težnje elita u Hrvatskoj i Sloveniji za većom regionalnom autonomijom, te optužuje vlasti $u$ Beogradu (u periodu između dva svetska rata) za represivnu politiku na prostorima Makedonije i Kosova. Jugoslovensko nacionalno pitanje je produkt nasleđa, kako je navela, ondašnje srpske represije. Autorka energično negira tezu o odgovornosti Tuđmanovog režima za srpsko-hrvatski rat 1991. godine, tvrdeći da je prve paramilitarne formacije organizovala srpska strana, te da su sukobe kako u Hrvatskoj tako i kasnije u Bosni i Hercegovini inicirale srpske snage. ${ }^{7}$ Ramet se pozabavila i istorijatom kosovske krize. „Kontrarevoluciju“ 1981. godine je izazvalo nezadovoljstvo kosovskih Albanaca zbog neuspeha vlasti u Beogradu da poboljša njihov životni standard. Pobuna je poprimila antisrpski karakter, što je zatim izazvalo reakciju srpske strane, smatra S. Ramet. ${ }^{8}$

U tekstu „The Last Ambassador. A Memoir of the Collapse of Yugoslavia“, objavljenom u Foreign Affairsu u proleće 1995. godine, koncizno su predstavljeni stavovi poslednjeg američkog ambasadora u SFRJ Vorena Zimermana o raspadu Jugoslavije. Analizirajući korene jugoslovenske krize, Zimerman značajan prostor posvećuje nacionalizmu jugoslovenskih naroda. „Tragičan defekt" Srba je njihova opsesija sopstvenom prošlošću. Njihova srca su u prošlosti a ne u budućnosti, konstatuje američki diplomata. Melanholični, paranoidni i srbocentrični pogled na prošlost je ono što omogućuje Srbima da za stvari koje krenu loše okrive sve osim sebe, ističe Zimerman. ${ }^{9}$ Nadovezujući se na analizu karaktera srpskog nacionalizma on izlaže i svoj pogled na političku odgovornost srpske strane za jugoslovensku krizu. Milošević nije bio zainteresovan za jugoslovensko jedinstvo „per se“, već samo za takav vid jugoslovenskog unitarizma koji bi obezbedio srpsku dominaciju u Jugoslaviji. Srpskog predsednika Zimerman je označio kao glavnog razbijača jugoslovenske federacije. ${ }^{10}$ Američki ambasador je fokusirao i krivicu drugih aktera jugoslovenske krize. Slovenci su u određenoj meri odgovorni za konflikte koji su usledili posle njihove secesije. U želji da se otcepe od Jugoslavije oni su ignorisali 22 miliona preostalih Jugoslovena.

\footnotetext{
${ }^{7}$ Sabrina Ramet, „War in the Balkans“, Foreign Affairs, 4 (1992), 80-82.

${ }^{8}$ Isto, 82.

${ }^{9}$ Warren Zimmermann, „The Last Ambassador. A Memoir of the Collapse of Yugoslavia", Foreign Affairs, 2 (1995), 3.

${ }^{10}$ Isto, 5.
} 
Zimerman poetski konstatuje: Njihova vrlina je bila demokratija, a njihov porok sebičnost. ${ }^{11}$

Značajnu odgovornost za eskalaciju jugoslovenske krize Zimerman je pripisao hrvatskoj strani. U tom kontekstu naveo je represivne postupke prema hrvatskim Srbima na početku HDZ-ove vladavine, poput otpuštanja iz službe, ugrožavanja njihove imovine. Hrvatski nacionalizam je netolerantan, antisrpski i autoritaran, sa aurom fašizma, što je sve, prema Zimermanu, pojašnjavalo odbijanje hrvatskih Srba da prihvate novu hrvatsku vlast. Zimerman je, kao ilustraciju agresivnog stava ondašnjeg hrvatskog rukovodstva prema srpskom stanovništvu, naveo da je i sam bio svedok rasističkih izjava hrvatskih ministara u vezi sa Srbima, na koje hrvatski predsednik nije reagovao. U Zimermanovom tekstu izneto je i poređenje dva ključna interna faktora jugoslovenske krize - Miloševića i Tuđmana. Miloševića je pokretala želja za moći, dok je Tuđman bio opsednut nacionalizmom. Ipak, prema autoru, postojala je još jedna bitna razlika - prozapadna orijentacija hrvatskog predsednika. ${ }^{12}$

Albanski nacionalizam je delimično predstavljao reakciju na, kako ističe Zimerman, Miloševićevu agresivnu taktiku. Kosovski Albanci su odlučili da bojkotuju parlamentarne izbore u Srbiji uprkos američkoj sugestiji da bi participacijom u srpskom parlamentu dobili veću političku snagu. ${ }^{13}$ Kritike u Zimermanovom tekstu ostala je pošteđena samo bošnjačka strana. Američki diplomata je Izetbegovića percipirao kao umerenog državnika, posvećenog muslimana (ne i ekstremistu), koji se dosledno zalagao za multietničku Bosnu. $^{14}$

Stav Alekse Đilasa, predstavljen u članku „A Profile of Slobodan Milošević“" u pogledu bošnjačke odgovornosti, odnosno odgovornosti njihovog ratnog lidera Alije Izetbegovića za eskalaciju jugoslovenske krize bio je nešto drukčiji. Raspadu jugoslovenske federacije doprineli su srpski i hrvatski nacionalizam, koje autor ocenjuje kao slične, te nacionalizam i muslimanski radikalizam Alije Izetbegovića. ${ }^{15}$ Đilas se fokusirao na motive i ponašanje srpske strane, ističući negativna istorijska iskustva iz dva svetska rata u kojima su Srbi pretrpeli značajne ljudske gubitke, kao i generalni osećaj Srba da ih je istorija "nepravedno tretirala“. Te žrtve su oblikovale svest Srba da im ostali jugoslovenski narodi duguju zahvalnost za 1918. i 1945. godinu. ${ }^{16}$

\footnotetext{
${ }^{11}$ Isto, 7.

${ }^{12}$ Isto, 7-8.

${ }^{13}$ Isto, 8.

${ }^{14}$ Isto, 9.

${ }^{15}$ Aleksa Djilas, „A Profile of Slobodan Milošević“, Foreign Affairs, 3 (1993), 93.

${ }^{16}$ Isto.
} 
Đilas je označio inteligenciju kao ključnog nosioca nacionalizma na prostorima ne samo bivše Jugoslavije već i na širem prostoru istočne i centralne Evrope, na koju je talas prosvetiteljstva u 18. veku tek površno uticao. Postoji velika zavisnost inteligencije u pomenutim delovima Evrope od države. Njen glavni poslodavac je bila i ostala država. Đilas podvlači odsustvo dublje ukorenjenih liberalnih, demokratskih institucija, čime se ugrožava razvoj pluralističke političke kulture. Svi ti faktori čine inteligenciju u ovom delu Evrope manje liberalnom u odnosu na inteligenciju Zapada, usled čega je ona spremna da liberalne i demokratske aspiracije žrtvuje u korist "nacionalnih interesa“, ocenjuje autor. ${ }^{17}$

Autor se $u$ članku bavi i Miloševićevim osvajanjem vlasti u Srbiji. Odgovornost za Miloševićev uspon Đilas posredno pripisuje Josipu Brozu Titu, koji je eliminišući kreativne snage u Savezu komunista Srbije ${ }^{18}$ rašči- $^{-}$ stio put za Miloševićev uspon do vrha partije srpskih komunista. Đilas je dao i svoje viđenje Miloševićevog koketiranja sa srpskim nacionalizmom $u$ ranom periodu njegove epohe.

Miloševića je na prihvatanje nacionalističkog pristupa motivisala procena da je najbolji način da se izbegne gnev masa stavljanje na njihovo čelo. Đilas je takvu strategiju Miloševića definisao kao „politički kanibalizam“. „Progutao" je srpski nacionalizam, ali je duh nacionalizma prožeo njegovo telo. ${ }^{19}$

Slične poglede na poreklo nacionalizma na prostorima bivše Jugoslavije na stranicama Foreign Affairsa izložio je i Vilijem Hejgn. I on je, kao i Đilas, snažan nacionalizam jugoslovenskih naroda doveo u vezu sa njihovim istorijskim razvojem.

Današnje balkanske države ne baštine zapadnu liberalnu tradiciju, koja stavlja akcenat na individualizam i zaštitu manjina. U tekstu je podvučena i njihova fokusiranost na razvoj nacionalnog identiteta. ${ }^{20}$ Hejgn naglašava ogorčenost srpskih nacionalista opadanjem srpskog uticaja u Titovoj Jugoslaviji, naročito posle pada Aleksandra Rankovića 1966. godine, i to posebno $u$ vezi sa pitanjem Kosova. U tekstu se zatim ističe Miloševićeva odluka da zaigra na kartu nacionalizma. Autor je negativno ocenio i druge lokalne aktere jugoslovenske krize, naglasivši da ostali balkanski (odnosno jugoslovenski) nacionalizmi suštinski nisu bili moralno superiorni u odnosu na srpski nacionalizam. Hrvatski, albanski i bošnjački nacionalizam se tokom ratova 90 -ih po sklonosti nasilju i autoritarizmu nisu razlikovali od srpskog nacionalizma. Kao ilustraciju te teze autor navodi sudbinu hrvat-

\footnotetext{
${ }^{17}$ Isto, 92.

${ }^{18}$ Misli se na obračun sa liberalima.

${ }^{19}$ A. Đilas, $n$. d., 85, 87.

${ }^{20}$ William W. Hagen, „The Balkans' Lethal Nationalisms“, Foreign Affairs, 4 (1999), 54.
} 
skih Srba posle akcije „Oluja“, kao i ekstremizam Oslobodilačke vojske Kosova. $^{21}$

Jugoslovenske tragedije se u pomenutom članku „The Clash of Civilizations?" dotakao i Semjuel Hantington, koji kao uzrok konflikata na prostoru bivše Jugoslavije 90 -ih godina prošlog veka ne navodi radikalan nacionalizam jugoslovenskih naroda.

U skladu sa svojom tezom o značaju civilizacijskog identiteta američki teoretičar je i jugoslovenski konflikt objasnio različitom civilizacijskom pripadnošću jugoslovenskih naroda. Padom komunizma ideološka gvozdena zavesa u Evropi zamenjena je plišanom zavesom kulture koja je, po Hantingtonu, ključna linija podele u Evropi. Ova zavesa je prolazila kroz Jugoslaviju, podudarajući se sa istorijskim granicama Habzburške monarhije i Otomanskog carstva. Zapadno i severno od te linije su katolici i protestanti, koji dele nasleđe evropske istorije - feudalizam, renesansu, reformaciju, prosvetiteljstvo, Francusku revoluciju, Industrijsku revoluciju. Reč je o narodima razvijenijih ekonomija od naroda istočno od pomenute zavese, o narodima okrenutim jačoj participaciji u zajedničkoj evropskoj ekonomiji i stabilizaciji demokratskih sistema, ocenjuje autor. ${ }^{22}$

Nasuprot njima, narodi istočno od te zavese samo su okrznuti procesima koji su oblikovali delove Evrope na drugoj strani zavese. Oni su generalno slabije ekonomski razvijeni i manje sposobni da razviju stabilne demokratske sisteme. U jugoslovenskom slučaju nije u pitanju bila samo linija različitosti već povremeno i linija krvavog konflikta, smatra Hantington. ${ }^{23}$

\section{Uloga međunarodnih aktera u jugoslovenskoj krizi}

Česta tema članaka o jugoslovenskoj krizi 90-ih godina objavljivanih tada u časopisu Foreign Affairs bila je politika međunarodne zajednice, odnosno ključnih zapadnih sila prema raspadu jugoslovenske federacije i ratovima koji su usledili. Kritički ili pozitivno, već prema orijentaciji autora, ocenjivani su najvažniji momenti uključivanja inostranog faktora u jugoslovensku krizu - poput međunarodnog priznavanja Hrvatske i Slovenije, pozicije Sjedinjenih Američkih Država prema konfliktima na prostoru bivše Jugoslavije u ranoj fazi krize, bombardovanja Savezne Republike Jugoslavije 1999. godine.

U pomenutom članku iz 1992. godine, „War in the Balkans“, Sabrina Ramet se podrobno bavila pozicijom Zapada u početnoj fazi jugosloven-

\footnotetext{
${ }^{21}$ Isto, 56, 60 .

${ }^{22}$ Samuel P. Huntington, „The Clash of Civilizations?", Foreign Affairs, 3 (1993), 30-31.

${ }^{23}$ Isto.
} 
skog krvoprolića. U delu posvećenom internacionalnom aspektu jugoslovenske krize ona je detaljno navela argumente $u$ prilog vojnoj intervenciji zapadnih sila $u$ bivšoj Jugoslaviji. Odlaganje upotrebe sile protiv srpske strane u ratu imalo bi za posledicu destabilizaciju celog regiona. Srpske snage bi proširile rat, što bi moglo dovesti do ulaska u rat Albanije, Bugarske, Grčke i Turske. Po Sabrini Ramet, vojna intervencija protiv srpskih snaga je trebalo da zaustavi srpsku ofanzivu pre nego što bi se rat proširio. Intervencija je predstavljala pitanje samoodbrane Zapadne Evrope i time je bila od strateškog interesa za Sjedinjene Američke Države, zaključuje Ramet. ${ }^{24} \mathrm{U}$ vezi sa potrebom međunarodne intervencije autorka je preporučila odgovarajuće poteze, anticipirajući donekle intervenciju Severnoatlantskog pakta protiv Savezne Republike Jugoslavije sedam godina kasnije. Vojnu akciju protiv srpskih snaga bilo bi moguće izvesti bez angažovanja kopnenih trupa, preciznim vazdušnim napadima na infrastrukturne i vojne objekte u Srbiji i Bosni. Istovremeno, Sabrina Ramet je pledirala za ukidanje embarga na prodaju oružja Sloveniji, Hrvatskoj i Bosni i Hercegovini, kao i za podršku u naoružanju Bošnjacima i bosanskim Hrvatima. ${ }^{25}$ Međunarodna vojna intervencija protiv srpske stane pomerila bi ravnotežu snaga na terenu u korist Bošnjaka i Hrvata, dok bi njen izostanak destabilizovao veliki deo Balkana i proizveo talas izbeglica, koji bi prevazišao apsorbujuće kapacitete zapadnoevropskih država. Sa druge strane, neintervenisanje bi značilo da je za Sjedinjene Države i Evropsku uniju Helsinška deklaracija samo mrtvo slovo na papiru, što bi predstavljalo opasan presedan. ${ }^{26}$

Pitanjem međunarodne participacije u jugoslovenskoj krizi bavio se i britanski pregovarač Dejvid Oven. Britanski diplomata je u intervjuu objavljenom 1993. godine u Foreign Affairsu kritikovao tajming priznavanja otcepljenih jugoslovenskih republika (posebno Hrvatske i Slovenije) od strane Evropske zajednice. Oven je izložio kritici i inertnu politiku Sjedinjenih Država u početnoj fazi jugoslovenskog rata. Izneo je stav o potencijalno pozitivnom ishodu eventualne međunarodne vojne intervencije, što je u saglasju sa mišljenjem Sabrine Ramet. Nespremnost međunarodne zajednice da vojno interveniše suzila bi diplomatski prostor za pregovore. Vazdušni udari bi, uz pojačavanje režima sankcija, mogli promeniti odnos snaga i primorati bosanske Srbe da prihvate mirovni plan - ocenjuje Oven. ${ }^{27}$

Iste teme nalazimo $\mathrm{u}$ članku „The Last Ambassador" poslednjeg američkog ambasadora u SFRJ Vorena Zimermana. On je, kako navodi, predlagao Vašingtonu da odloži priznavanje otcepljenih republika, te da je i

\footnotetext{
${ }^{24}$ S. Ramet, $n . d ., 96-97$.

${ }^{25}$ Isto.

${ }^{26}$ Isto, 97-98.

${ }^{27}$ David Owen, „The Future of the Balkans“, Foreign Affairs, 2 (1993), 2-5.
} 
rukovodstvu bosanskih Muslimana ${ }^{28}$ savetovao da sačekaju sa molbom Evropskoj zajednici da prizna Bosnu i Hercegovinu. Činjenicu da je bošnjačko rukovodstvo zauzelo drugačiji kurs prema tom pitanju američki diplomata je označio kao „katastrofalnu političku grešku“, budući da je time srpska strana dobila povod za akciju. Prema srpskom tumačenju priznanjem nezavisnosti Bosne i Hercegovine 1,3 miliona Srba u BiH odvojeno je od Jugoslavije protiv svoje volje. ${ }^{29}$ Zimerman piše i o američkoj odgovornosti za dramatična događanja na prostoru bivše Jugoslavije. S tim u vezi posebno fokusira čuvenu posetu Jugoslaviji američkog državnog sekretara Džejmsa Bejkera, pri čemu koncizno podseća na Bejkerove poruke jugoslovenskim liderima.

U razgovoru sa Tuđmanom i Kučanom Bejker je poručio da Sjedinjene Države neće ohrabriti ili podržati unilateralnu secesiju, izrazio nadu da oni neće ići na otcepljenje i zatražio da, u slučaju odluke da izađu iz Jugoslavije, to urade putem dijaloga i na miran način. Miloševiću je državni sekretar predočio da se Sjedinjene Države snažno protive upotrebi sile. Od srpskog predsednika je tražen i pristanak na labavije konstitucionalno uređenje Jugoslavije. ${ }^{30}$

Analizirajući posetu Bejkera Jugoslaviji juna 1991. godine, Zimerman odbacuje kritike da je time dato zeleno svetlo Miloševiću, odnosno Jugoslovenskoj narodnoj armiji da napadne republike koje su započele proces otcepljenja od Jugoslavije. Ipak, nije bilo ni crvenog svetla budući da Sjedinjene Države nisu najavile upotrebu sile u cilju sprečavanja vojnog napada na Sloveniju i Hrvatsku. Bejkerova poruka je bila ispravna, ali je došla prekasno zbog američke okupiranosti „masivnim“ pripremama za Zalivski rat. Ostaje nejasno da li bi i da je do posete državnog sekretara Bejkera došlo ranije jugoslovenska kriza imala drugačiji ishod, priznaje Zimerman. ${ }^{31}$

Međunarodna vojna intervencija protiv srpskih snaga u početnoj fazi jugoslovenskih ratova imala bi pozitivne posledice, navodi Zimerman. U tom kontekstu američki diplomata je pomenuo dubrovačko ratište konstatujući da su artiljerijske pozicije Jugoslovenske narodne armije oko Dubrovnika, kao i njene pomorske snage na tom prostoru predstavljale laku metu. Međunarodnom (NATO) intervencijom postigla bi se dva cilja: bilo bi izbegnuto oštećenje grada, dok bi demonstrirana odlučnost Zapada možda odvratila srpsku stranu od potonje ofanzive u Bosni. Izostankom vojne intervencije Zapada Srbima je, smatra američki diplomata, poručeno da mogu

${ }^{28}$ Zimerman navodi da je takav savet dao Ejupu Ganiću, koga je u tekstu okarakterisao kao muslimanskog jastreba.

\footnotetext{
${ }^{29}$ W. Zimmermann, n. d., 16-17.

${ }^{30}$ Isto, 11.

${ }^{31}$ Isto, 11-12.
} 
da idu onoliko daleko dokle im omogućava njihova sopstvena moć. ${ }^{32}$ Zimer- $^{2}$ man je i Bušovoj i Klintonovoj administraciji prebacio nespremnost da se vojno interveniše u Bosni uprkos značajnim američkim interesima na Balkanu. Važno je napomenuti da je članak „The Last Ambassador" izašao u proleće 1995. godine, pre NATO operacije Deliberate Force u Bosni i Hercegovini ${ }^{33}$ i znatno pre rata na Kosovu 1998/1999. godine, koji je okončan intenzivnim angažmanom američkih oružanih snaga. Da je tekst napisao nešto kasnije, a posebno posle 1999. godine, Zimerman svakako ne bi mogao da prebaci Klintonovoj administraciji pasivnost u balkanskim poslovima.

Jednako kritičan prema američkoj politici u Bosni i Hercegovini, odnosno prema izostanku američke vojne intervencije u BiH bio je i Miša Gleni. U članku „Heading Off War in the Southern Balkans“, objavljenom takođe pre operacije Deliberate Force u Bosni i Hercegovini, Gleni je kritikovao neodlučnost Klintonove administracije u bosanskom ratu. Vlada u Sarajevu se oseća izdanom od strane Vašingtona s obzirom na američku retoričku podršku ujedinjenoj Bosni, koja nije bila podržana silom, ocenjuje Gleni. Bela kuća je trebalo da uradi jednu od dve stvari - da upotrebi silu u cilju podrške vladi u Sarajevu, ili da jasno naglasi da nema takvih namera. Ključni problem politike Sjedinjenih Država prema ratovima u bivšoj Jugoslaviji bila je nemogućnost američke administracije da identifikuje američke interese u Hrvatskoj i Bosni i Hercegovini, smatra Gleni. ${ }^{34}$

Kritiku zapadnog kriznog menadžmenta u jugoslovenskim ratovima izneo je i Vilijem Hejgn. U članku „The Balkans' Lethal Nationalisms“ Hejgn ocenjuje da je Zapad pogrešio time što priznanje Hrvatske nije uslovio čvrstim garancijama za srpsku manjinu u Hrvatskoj, što bi imalo pozitivne posledice ne samo na zbivanja u Hrvatskoj već i u Bosni i Hercegovini, pa i na Kosovu. Garantovanje prava srpske manjine u Hrvatskoj i Bosni 1991-1992. godine otvorilo bi mogućnost da se izvrši pritisak na Miloševića da ponudi jednake garancije, uključujući i autonomiju, kosovskim Albancima. Na taj način mogla je biti izbegnuta kriza na Kosovu 1998/99. godine, zaključuje autor. ${ }^{35}$

Posebno oštru kritiku zapadne (NATO) politike u jugoslovenskoj krizi, i to u događanjima na Kosovu 1999. godine, nalazimo u članku Majkla Mendelbauma, „A Perfect Failure. NATO's Was Against Yugoslavia“. Napad NATO na Saveznu Republiku Jugoslaviju 1999. godine samo je pogoršao stanje na terenu, broj žrtava sukoba na Kosovu posle početka va-

${ }^{32}$ Isto, 14.

${ }^{33}$ U okviru operacije Deliberate Force, koja je započela 30. avgusta 1995. NATO je intenzivnim vazdušnim udarima napao položaje bosanskih Srba.

${ }^{34}$ Misha Gleny, „Heading Off War in the Southern Balkans“, Foreign Affairs, 3 (1995), 99-100.

${ }^{35}$ W. W. Hagen, $n$. d., 59-60. 
zdušnih udara NATO na srpske položaje bio je višestruko veći nego pre 24. marta 1999, većinu žrtava činili su albanski civili koje su ubile srpske snage, ocenjuje Mendelbaum. Posle početka bombardovanja znatno se uvećao broj kosovskih Albanaca koji su napustili Kosovo, a u tom kontekstu Mendelbaum podseća kako je jedan od ciljeva Klintonove administracije 1999. godine bio spasavanje života ljudi. Negativna posledica NATO kampanje protiv SR Jugoslavije bila je i destabilizacija situacije u regionu. Priliv velikog broja izbeglica sa Kosova pretio je da poremeti „politički balans“ između Makedonaca i Albanaca u Makedoniji, srpske akcije na zemlji i napadi NATO iz vazduha devastirali su veliki deo Kosova, dok su NATO bombardovanja značajno oštetila infrastrukturu u Srbiji - ocenjuje autor. ${ }^{36}$

U članku je kritički analiziran legitimitet NATO kampanje protiv Savezne Republike Jugoslavije. Mada međunarodno pravo zabranjuje mešanje $u$ unutrašnje stvari jedne suverene zemlje, u dva slučaja bilo bi dozvoljeno da se ovo pravilo prekrši, smatra Mendelbaum. Ipak, nijedan od ta dva uslova u slučaju rata na Kosovu nije bio ispunjen. Prvi uslov koji bi opravdao takvu međunarodnu intervenciju bio bi veliko kršenje ljudskih prava na terenu, što se na Kosovu nije dogodilo. Autor kritikuje srpski odnos prema kosovskim Albancima, ali smatra da na Kosovu nije bilo najradikalnijih kršenja ljudskih prava. Takvu tezu argumentuje zapažanjem da je na Kosovu pre NATO kampanje bilo znatno manje žrtava nego u sukobima u Sijera Leone, Sudanu ili u Ruandi, gde nije došlo do intervencija NATO. Drugi neispunjeni uslov koji bi legitimizovao strano vojno uplitanje $u$ događanja $u$ jednoj suverenoj zemlji bila bi autorizacija Ujedinjenih nacija. ${ }^{37}$

Značajna negativna posledica američkog, odnosno NATO angažmana u Saveznoj Republici Jugoslaviji 1999. godine bilo je zaoštravanje odnosa Sjedinjenih Država sa njihovim najvećim rivalima - Rusijom i Kinom. Akcije NATO protiv SRJ ubrzale su pogoršavanje odnosa Zapada sa Rusijom, koje je pokrenuto uključivanjem Poljske, Češke i Mađarske u Severnoatlantski pakt, ocenjuje autor. U tekstu je podvučeno jačanje antiameričkih sentimenata u Kini kao posledica bombardovanja kineske ambasade u Beogradu tokom vazdušnih udara NATO protiv SR Jugoslavije 1999. godine. ${ }^{38}$

$\mathrm{Na}$ Mendelbaumovu oštru kritiku NATO intervencije protiv Savezne Republike Jugoslavije jednako oštro je na stranicama Foreign Affairsa odgovorio Džejms Steinberg. U članku „A Perfect Polemic. Blind to Reality on Kosovo" Steinberg iznosi stav da bi se u slučaju da nije došlo do akcije NATO, pojačala humanitarna kriza izbeglih kosovskih Albanaca. Izostanak

${ }^{36}$ Michael Mandelbaum, „A Perfect Failure. NATO's War Against Yugoslavia“, Foreign Affairs, 5 (1999), 2-3.

${ }^{37}$ Isto, 5-6.

${ }^{38}$ Isto, 7. 
ulaska NATO u kosovski sukob ojačao bi Miloševića, te bi potencijalni diktatori u regionu zaključili da njihovo nasilje ne bi izazvalo reakciju međunarodne zajednice. Nedelovanje NATO bi moglo da dovede do širenja konflikta, odnosno do uvlačenja susednih zemalja u rat. ${ }^{39}$ Steinberg osporava i Mendelbaumovu tezu da je intervencija NATO 1999. godine dovela do pogoršanja odnosa Sjedinjenih Država sa Rusijom i Kinom. U vezi s tim Steinberg ukazuje na "refokusiranje“ Vašingtona i Moskve na „njihove zajedničke interese“, navodeći kao primer ratifikovanje sporazuma Start II. Kao ilustracija neporemećenih odnosa SAD i Kine naveden je susret Bila Klintona i kineskog predsednika Đang Cemina septembra 1999. ${ }^{40}$

Logično pozitivan stav o neophodnosti vazdušnih udara NATO protiv Savezne Republike Jugoslavije izneo je u Foreign Affairsu nekadašnji (1995-1999) generalni sekretar Severnoatlantskog pakta Havijer Solana. Rizik intervencije bio je opravdan, budući da bi nedelovanje NATO značilo da „atlantska zajednica“ legitimizuje etničko čišćenje, ocenjuje Solana. Pasivnost Severnoatlantskog pakta u kosovskoj krizi bi potkopala transatlantske odnose i kredibilitet zapadnih institucija. ${ }^{41}$

\section{Šta posle rata? Analize posleratnog stanja na prostoru bivše Jugoslavije}

Deo članaka objavljenih u Foreign Affairsu bavio se postkonfliktnom situacijom u bivšoj Jugoslaviji. Procenjivane su mogućnosti pomirenja, političkog i ekonomskog napretka u ratom uništenim područjima. Davane su, uz to, preporuke međunarodnim faktorima uključenim u regulisanje posleratnih procesa u bivšoj Jugoslaviji.

U pomenutom članku „The Balkans' Lethal Nationalisms“ Vilijem Hejgn se bavio i spekulisanjem o budućnosti Srbije posle bombardovanja 1999. godine, pokušavajući da pronađe paralele sa procesima u Zapadnoj Nemačkoj posle Drugog svetskog rata. Ipak, takvu paralelu nije uspeo da uspostavi.

Nemačka politička kultura mogla se posle rata osloniti na „autentične tradicije modernog liberalizma i kosmopolitizma“, oličene u ličnosti Konrada Adenauera. Sjedinjene Države su, uz to, Saveznu Republiku Nemačku podržale stotinama miliona dolara. Da li je NATO spreman na takvu investiciju u poraženoj Srbiji, zapitao se Hejgn. ${ }^{42}$

${ }^{39}$ James B. Steinberg, „A Perfect Polemic. Blind to Reality on Kosovo“, Foreign Affairs, 6 (1999), 130-131.

${ }^{40}$ Isto, 131-132.

41 Javier Solana, „NATO's Success in Kosovo“, Foreign Affairs, 6 (1999), 117-118.

${ }^{42}$ W. W. Hagen, n. d., 61. 
Hejgn sagledava dva moguća ishoda NATO kampanje protiv Savezne Republike Jugoslavije - NATO okupaciju Srbije, ili svođenje Srbije na očajnu i poraženu otpadničku državu koja bi predstavljala pretnju susednim zemljama. Prekidom bombardovanja ili nastavkom vojne akcije protiv SRJ, NATO treba da natera Miloševića na sledeće ustupke: povratak izbeglih kosovskih Albanaca i prisustvo na Kosovu NATO-a ili drugih međunarodnih trupa. Autor je, ipak, bio protiv bacanja Srbije na kolena, pa je srpskoj strani predložio određene ustupke: garancije za srpske interese na Kosovu, kompenzacije Srbima izbeglim iz Hrvatske, kao i ekonomske ustupke Srbiji. Takav mir otvorio bi put jačanju liberalnih i demokratskih pokreta u Srbiji, ocenjuje Hejgn. ${ }^{43}$ Potrebno je da se na Kosovu poštuju liberalno-demokratske vrednosti, da se Albanci kako na Kosovu tako i u Albaniji ohrabre da napuste „kolektivistički nacionalizam“, kao i da se garantuje da albanski iredentizam neće destabilizovati Makedoniju. Hejgn je postavio i pitanje: ko bi i na koji način pokrenuo takve procese, ali na njega nije dao odgovor. $^{44}$

Ivo Dalder i Majkl Fromen se bave situacijom u postdejtonskoj Bosni. U članku „Dayton's Incomplete Peace“, objavljenom u Foreign Affairsu četiri godine po zaključenju Dejtonskog mirovnog ugovora, oni su u tamnim nijansama prikazali situaciju u postkonfliktnoj Bosni i Hercegovini. U Bosni i Hercegovini, kao i pre Dejtona, dominiraju nacionalističke politike i etničke podele, a slaba privredna aktivnost oslonjena je jedino na stranu pomoć. Njihov pesimizam kulminira u tvrdnji da multietnička, demokratska i ekonomski održiva Bosna i Hercegovina neće biti ostvarena ukoliko narodi Bosne i međunarodna zajednica ne promene „aktuelnu trajektoriju“. $\mathrm{U}$ vezi sa funkcijom međunarodne zajednice u dejtonskoj Bosni, autori naglašavaju slabu realnu moć OHR (Kancelarije visokog predstavnika). ${ }^{45}$

Sredinom 2000. godine Dejvid Rodi je u Foreign Affairsu predstavio svoje viđenje stanja na Kosovu godinu dana posle završetka rata. I u Rodijevom tekstu dominira pesimizam. Posleratno Kosovo autor vidi kao prostor razvijene korupcije, bezakonja, netolerancije prema etničkim i političkim manjinama. Situacija na Kosovu je još više obeshrabrujuća nego u Bosni i Hercegovini. Otuda, prema autoru, ključni cilj međunarodne zajednice na Kosovu treba da bude podržavanje umerenih političkih struja na Kosovu, odnosno uspostavljanje uslova koji bi omogućili umerenim Albancima da stvore etnički tolerantno Kosovo. ${ }^{46}$

${ }^{43}$ Isto, 64.

${ }^{44}$ Isto, 61.

${ }^{45}$ Ivo H. Daalder, Michael B. G. Froman, „Dayton's Incomplete Peace“, Foreign Affairs, 6 (1999), 106-113.

${ }^{46}$ David Rohde, „Kosovo Seething“, Foreign Affairs, 3 (2000), 66. 
Rodi je fokusirao i pitanje budućeg statusa Kosova, ocenivši da Kosovo nije spremno za nezavisnost. Autor je ponovo ukazao na problem organizovanog kriminala, bezakonja, napada na pripadnike srpske zajednice. Nezavisnost Kosova bi i u spoljnopolitičkom smislu bila teško održiva. U tom slučaju, nezavisno Kosovo bilo bi potrebno štititi isporukama teškog naoružanja ili prisustvom trupa NATO, s obzirom na moguću srpsku intervenciju. Otežavajuća okolnost u slučaju proglašenja nezavisnosti Kosova bilo bi i moguće protivljenje Rusije i Kine takvoj promeni statusa Kosova. Autor se izjasnio i protiv moguće podele Kosova, tvrdeći da bi takav presedan podstakao secesionističke težnje u regionu. ${ }^{47}$ Dejvid Rodi je predložio i svoju varijantu budućeg statusa Kosova. Pod uslovom da Milošević bude sklonjen sa vlasti (članak je objavljen nekoliko meseci pre pada Miloševićevog režima), Kosovo bi moglo da uđe u labavu konfederaciju sa Srbijom i Crnom Gorom. ${ }^{48}$

Početkom 2001. godine, samo nekoliko meseci posle Miloševićevog pada, u Foreign Affairsu koncizan pregled stanja u postkonfliktnim delovima bivše Jugoslavije dao je i švedski diplomata Karl Bilt. Opis situacije u Bosni i Hercegovini dosta je sličan ocenama stanja u članku Daldera i Fromena. I posle velikog paketa pomoći za dejtonsku Bosnu, koju Bilt upoređuje sa Maršalovim planom, zemlja je ostala u velikoj meri zavisna od strane podrške. Trgovinski deficit je ogroman, domaćih investicija nema, budžet je neodrživ, nezaposlenost masovna, a institucije korumpirane i neefikasne. Blokada ekonomskog razvoja, po Biltu, posledica je činjenice da je za većinu bosanskih lidera mir predstavljao nastavak rata drugim sredstvima. Otuda stara nacionalna pitanja i dalje dominiraju njihovim agendama, potiskujući socijalne i ekonomske teme. Međunarodna zajednica, po Biltovom mišljenju, treba da pomogne da se u Bosni uspostave institucije koje bi osigurale vladavinu prava i da se konstruiše jak politički okvir koji bi okončao unutrašnju nestabilnost. Autor ukazuje i na značaj uključivanja Bosne u regionalne i evropske integracije. ${ }^{49}$

Situacija u Srbiji je prvih meseci post-Miloševićeve ere, po oceni švedskog diplomate, bila gora nego u dejtonskoj Bosni. Srpske institucije su bile oblikovane devastirajućom kombinacijom socijalizma, sankcija, mafije i nomenklature. Srbiju treba podržati u sprovođenju fundamentalnih reformi, ali i u suočavanju sa prošlošću (ratovima 90-ih), u čemu, prema autoru, posebnu ulogu treba da odigra Haški tribunal. Da bi ispunio taj zadatak

\footnotetext{
${ }^{47}$ Isto, $76-77$.

${ }^{48}$ Isto.

${ }^{49}$ Carl Bildt, „A Second Chance in the Balkans“, Foreign Affairs, 1 (2001), 152-153.
} 
Haški tribunal bi morao da se percipira ne kao instrument odmazde već kao instrument pomirenja, smatra Bilt. ${ }^{50}$

Članak upućuje na zaključak da uticajni švedski diplomata u tom trenutku (kraj 2000 - početak 2001) nije bio pristalica nezavisnosti Kosova. Bilt je podvukao da se region (osim, razume se, Albanije) protivi takvom ishodu, smatrajući ga opasnim i destabilizujućim. Rešenje statusa Kosova Bilt je tada sagledavao na sličan način kao i Dejvid Rodi. Odbacio je mogućnost da Beograd nastavi da upravlja Kosovom, ali je istovremeno ukazao na potrebu da Kosovo bude spremno na neku vrstu saveza sa Srbijom i Crnom Gorom: „But it must be ready to share with Serbia and Montenegro certain powers within a reformed framework clearly linked to European integration." 51

Balkan (posle 2000. godine) dobio je novu šansu i precizirao unutrašnje i spoljne preduslove da se ona iskoristi, zaključuje Bilt. Da bi se izgradila samoodrživa stabilnost u regionu balkanski lideri bi morali da odustanu od preokupacije devetnaestovekovnim konceptom nacionalne države i prihvate ideju transnacionalne integracije koja će oblikovati Evropu u 21. veku. Bilt je odbacio uverenje da međunarodna zajednica balkanske probleme može rešiti samo „pametnim“ bombama, ocenivši da je 90-ih godina na Balkanu nedostajalo ipak nešto drugo - pametna politika. ${ }^{52}$

\footnotetext{
${ }^{50}$ Isto, 153-154.

${ }^{51}$ Isto, 154-158.

${ }^{52}$ Isto.
} 
Petar Dragišić

\section{THE ARTICLES IN THE FOREIGN AFFAIRS MAGAZINE ON THE WARS IN YUGOSLAVIA 1991-1999}

\section{Summary}

The Foreign Affairs journal is an important asset for analysis of American foreign policy and the most important global topics for nearly a century. In the 1990-ties many of the authors in this journal dealt with the issue of Yugoslavia - the disintegration of the Socialist Federal Republic of Yugoslavia and a series of wars that followed on its former territory. The Yugoslav crisis was analyzed by the different authors: theorists, prominent journalists, and politicians that were directly involved in different stages of the Yugoslav crisis, such as David Owen, Warren Zimmerman or Carl Bildt. Most of the attention was devoted to the conflicts in Bosnia and Herzegovina and Kosovo. The causes of the Yugoslav tragedy were analyzed, in many articles on the Yugoslav wars in the 1990s, published in Foreign Affairs, with a special focus on origins of internal tensions that preceded the tragic collapse of the Yugoslavia. The most frequent topic of those articles, was the role of foreign factors in crisis and wars in the former Yugoslavia. The issue of international recognition of the breakaway Yugoslav republics at the beginning of the wars, and NATO air strikes against the Federal Republic of Yugoslavia in 1999 was specifically addressed. Several Foreign Affairs articles published the nineties and the early years of the millennium evaluated of the political situation in countries of the former Yugoslavia in the post-conflict period. Common to almost all authors who were analyzing this subject are negative remarks on the post-war development in parts of the former Yugoslavia, which were mostly affected by the crisis and wars of the 90s. An integral part of the contence in those articles, were recommendations of authors to those international actors who are able to influence the processes in the former Yugoslavia. 